Deliberationes tudományos folyóirat

14. évfolyam 1. szám 2021/18-24

Kézirat beérkezése: 2021.04.15.

Kézirat befogadása: 2021.08.16.

DOI: 10.54230/Delib.2021.1.18
Deliberationes Scientific Journal

Vol.14; Ed.No. 1/2021, pages: 18-24

Paper submitted: 15th April 2021

Paper accepted: 16th August 2021

DOI: $10.54230 /$ Delib.2021.1.18

\title{
A POSZTMODERN IFJÚSÁG MINT AZ ISTENTISZTELETIKÖZÖSSÉG ÉPÍTÉSÉNEK KÜLÖNLEGES KIHÍVÁSA
}

\author{
Czagány Gábor \\ Gál Ferenc Egyetem, Gazdasági Kar
}

\begin{abstract}
Absztrakt
Ebben a tanulmányban bemutatjuk a kapcsolatot a vallásos személyiség fejlödése és az istentisztelet formája közt. A fiataloknak sok tekintetben egyedi szükségleteik vannak, amely alól a vallás sem kivétel. Épp ezért az istentiszteleti formáknak figyelemmel kell lenniük ezekre a szükségletekre. Témánk bemutatása során többek között James Fowler vallásfejlődési elméletére és Piet Fransenre is utalunk, aki érdekes párhuzamot von a népi vallásosság, az ortodoxia istentisztelete és a posztmodern fiatalok hite közt.
\end{abstract}

Kulcsszavak: ifjúság, istentisztelet, posztmodern, közösségépítés

\section{THE POSTMODERN YOUTH AS A SPECIAL CHALLENGE OF WORSHIP COMMUNITY BUILDING}

\author{
Gábor Czagány \\ Faculty of Economy, Gál Ferenc University
}

\begin{abstract}
In this article, we present the relationship between the development of religious personality and form of worship service. Young people have special needs in all respects, including religious life. Forms of worship should take these needs into account. In presenting the topic, among others, we refer to James Fowler's theory of religious development and to Piet Fransen, who draws an interesting parallel between folk religiosity, the worship of orthodoxy, and the religiosity of (post) modern youth.
\end{abstract}

Keywords: youth, worship, postmodern, community buliding 
Az életkorok pszichológiájának könyvtárnyi irodalma van, ezért ebben a rövid dolgozatban csak egyetlen klasszikus példán keresztül, James Fowler egyéni vallási fejlődési szakaszainak logikáját követve érintjük a vizsgált korosztály pszichológiai adottságait. E jellemzők általános érvényűsége vitatott, de azt mindenképpen látni kell, hogy - ahogyan azt gyakorlati kutatások is igazolják - a hit fejlődését Fowler rendszere jól körülírja.

Fowler szerint az egyetemi tanulmányok időszakában és az ezzel megegyező életkorban a legjellemzőbb az individuatív-reflektív hit, amely skáláján a negyedik helyet foglalja el.

Szerinte azonban sokan megmaradnak a harmadik fokozatban, amely a szintetikus-konvencionális hit szintje. Ez utóbbi legfontosabb jellemzője, hogy az ezen a szinten lévő ember nem bontja meg a készen kapott hitrendszert, hanem adottnak tekinti azt. Az a meggyőződés, hogy ez így helyes, az elöző szintekhez képest itt sokkal személyesebb jelleget ölt. Mindez nagy, felekezet iránti elkötelezettséget jelent, ugyanakkor azzal a veszéllyel jár, hogy az egyén túlságosan kiszolgáltatja magát mások elvárásainak és szempontrendszerének (P. Tóth, 1996).

$\mathrm{Az}$ individuatív-reflektív fázis legfontosabb jellemzője, hogy megrendül a különböző tekintélyekbe vetett bizalom és emiatt a formálódó személyiségek rákényszerülnek az értékek eredetének valamint relativitásának vizsgálatára. Ez sokak számára zavaró bizonytalanságot, másoknak viszont a felszabadulás és a nagy emancipáció érzését hozza meg. Ezen a szinten az ember a saját örökölt világképét, tantételeit megvizsgálja és kritika tárgyává teszi. Ennek nyeresége a megküzdött, személyessé vált és letisztult nézet lehet, amelyet a fiatal teljesen személyesnek érezhet (P. Tóth, 1996).

Már egyetemista korú fiatalok esetében is elöfordulhatnak, a Fowler által leírt ötödik szintre, a konjunktív hitre jellemző sajátosságok. Ennek a hitnek kiindulópontja az a felismerés, hogy a világ kérdéseit nem lehet végletesen és adekvát módon puszta kritikai, intellektuális tisztázással megoldani. Ebben az állapotban a fiatal képes nyitott szívvel értékelni más hitek, illetve tradíciók értékeit, alázatosan elismerve, hogy a végső igazság túl van az egyes felekezeteken, beleértve a magáét is és még a szimbólumok sem képesek maradéktalanul kimeríteni a transzcendens valóságát (P. Tóth, 1996).

$\mathrm{Az}$ istentisztelet egészének - ahogyan az egész egyházi munkának - valamilyen formában a vallásos személyiség fejlődését kell szolgálnia. A fentebb, vázlatosan ismertetett rendszer elemeit használva, az istentisztelet mindenekelőtt ki kell, hogy emeljen a megszokottból, a konvenciálisból és a mások által meghatározott istenképből. Ezzel párhuzamosan a szertartásnak helyet kell biztosítani az egyéni reflexióra és teret arra, hogy az egyén személyesen találkozhasson Istennel, hogy ezáltal minél többet megérthessen saját életére vonatkozóan. Az istentiszteletnek abban is segítenie kell, hogy minél több téren nyíljon lehetőség az egyéni képességek kibontakoztatására, az aktivitásra, hiszen ez az önállósodó személyiség fontos igénye. Vé- 
gezetül pedig, figyelembe véve a hit fejlődésének irányát, a liturgia lehetőleg minél több szimbólumot kell használjon az Istenről való gondolkodás fejlődése érdekében.

Összefoglalva, a hit fejlődésének pszichológiája arra biztat, hogy az istentisztelet legyen:

1. átalakító erejü, kifelé fordító;

2. önállóságra nevelő, reflexióra késztető;

3. aktivizáló;

4. szimbolikus.

Az istentiszteletnek azonban nem az emberi személyiség kibontakoztatása a legföbb célja. Az istentisztelet mindig Isten dicséretére irányul. Mivel a fiatalokra sok szempontból jellemző az Isten felé való nyitottság, létezik egy csatorna, amelyen keresztül szinte természetes módon indul el az Isten dicső́tése.

A fiatalok döntéseik nagyobb részét a szívükkel hozzák meg. Ebből következően jobban befogadják Isten kegyelemteljes szerető jelenlétét is és képesek arra, hogy önmagukat adják másoknak.

Ehhez a korosztályhoz azonban különleges hozzáállás szükségeltetik. Habár a lelki formálódás a fiatalok esetében is az imago Dei helyreállítását és elmélyítését jelenti, itt nem csak pusztán lelki folyamatról van szó. Sok keresztény azt gondolja, hogy a hit pusztán lelki természetủ. Valójában a formálódás a testet is érinti és használja a gesztusokon, a gyakorlatokon, a mozdulatokon keresztül. A tudás sem egyértelműen szellemi természetü. Arisztotelész például a gyakorlati tudásról (praxis) beszél, tehát a tenni akarásra koncentrál, nem úgy, mint az elméleti tudás. Arisztotelészt szabadon értelmezve ezt azt jelenti, hogy a fiatalok nem iskolában ülve sajátítják el a szükséges tudást, hanem egész egyszerűen gyakorolják az életet. Ez a Krisztusra alapozott lelki formálódásról szóló újfajta felfogás abban különbözik a hagyományos keresztény pedagógiától, hogy itt a fiatalokat meghívják a hívő élet gyakorlására (Edie, 2007).

A pszichológiai kutatásokat és összefüggéseket azok a szociológiai felismerések is alátámasztják, amelyek rámutatnak, hogy a mai ifjúság vallásossága sokszor nem igazítható az intézményes egyházak nyújtotta lehetőségekhez. Csákány Tamás az egyetemisták közötti misszió lehetőségeiről írva jegyzi meg, hogy a mai ifjúság körében egy új típusú vallásosság kezd kialakulni. Ez annyiban különbözik a tradicionális vallásosságtól, hogy tudatosabb és sokkal inkább az egyéni döntéseken, mint gyermekkori élményeken alapul. E fiatalok inkább keresik a közösségi - elsősorban kisközösségi - élményeket, mint a hagyományos keretek közt zajló, kiüresedett kereteket. A mai fiatalok különösen is igénylik, hogy ne csak helyük, de feladatuk is legyen egy közösségben. Ennek hiánya esetén nem magát Krisztust, hanem az intézményes kereteket kérdőjelezik meg (Csákány, 2001). 
Mindez azt is bizonyíthatná, hogy nincs is szükség kötött istentiszteletekre, hanem elegendőek a Biblia köré szervezett kötetlen együttlétek is. Ha azonban a 20 év körüli fiatalok általános személyiségvonásait tarjuk szemünk előtt, akkor láthatjuk, hogy az istentiszteleti forma, ahol a közösség valamilyen megfogató formában van jelen, meglehetősen sokat adhat a fejlődő hit számára.

Az ifjúsági istentisztelet egy nagyon fontos vonására egy római katolikus szerző, Piet Fransen hívja fel a figyelmet. Vallásszociológiai kutatásokra alapozva érdekes párhuzamot von a népi vallásosság, az ortodoxia istentisztelete és a (poszt)modern ifjúság vallásossága között. A megfigyelések lényege az, hogy az összes említett vallásgyakorlati forma nagyon közel áll a mindennapi élethez. A népi vallásosság, amely az év és az élet jeles napjait, évfordulóit nagyszabású ünnepekkel üli meg, közvetlenül reflektál az élet történéseire. A hagyományok alapja egy generációkon átívelő bölcsesség, ám maga a gyakorlati megnyilvánulás, e vallási cselekedetek jellegzetes karaktere kifejezetten életteli. Ugyanígy központi az ünnepi karakter a keleti egyház gyakorlatában, amely azonban minden korban hangsúlyozta, hogy a legmagasabb rendü istentisztelet az „élet liturgiája”, azaz a mindennapokban végrehajtott, keresztyén hitből fakadó cselekedet.

Bár az ortodoxiát gyakran, mint elvont, életidegen kultuszt értékelik, mégis teljesen világos, hogy képes arra, hogy a gyakorlati keresztyénségre vonatkozó üzenetét átadja az „egyszerü” hívők számára. Így az ünnep és a cselekedetek itt is kölcsönhatásban maradnak (Fransen, 1985).

Az ifjúsági istentiszteletnek is hordoznia kell a két előbbi példában látott „fesztivál" karaktert. Az életkori és kulturális sajátosságok ugyanis közvetlen dialógusba kezdenek az egyház átadta örökséggel. Ha a kettő között nincs élő kölcsönhatás, akkor maga a vallásosság is kikerül abból a kontextusból, amely igazából értelmet ad neki. Fransen kiváló összefoglalása arra mutat rá, hogy a szentségeket, így az eukarisztiai közösséggel egybekötött istentiszteletet is igazi ünnepnek (celebration) kell tekinteni. Ez nem távolítja el az istentiszteletet a hétköznapoktól, hanem ellenkezőleg épp közelebb viszi hozzá (Fransen, 1985).

Ha a fiatalkort, mint gyülekezetépítési kihívást nem a pszichológia és a vallásszociológia kategóriáiban, hanem a kortárs kultúra szemszögéből vizsgáljuk, úgy másfajta feladatokat körvonalazhatunk. Ezek a feladatok sok tekintetben általánosan érvényesek az egyházi munkára, ám különösen is hasznosak lehetnek a fiatalokkal kapcsolatos kezdeményezések kapcsán.

A mai kor egészére igaz, hogy nincs hiány élményekben. Egy gyors autó vezetési élményt ad, milliók nézik a TV-t és fogadnak be más, a média által kínált élményeket, kalandtúrákat szerveznek, hogy az emberek betölthessék az izgalom iránti szenvedélyes vágyukat. Ezek azonban mind önmegvalósító élmények. Az egyháznak nem szabadna ilyeneket nyújtania. Mégis komoly probléma, hogy sok gyülekezet, főként a fiatalok esetében, meglehetősen kritikátlan módon fogadja be ezeket a kulturális eszközöket és használja az élményeket adó termékeket. Eközben az egy- 
ház alkalmazkodik ahhoz a mai nézethez, hogy egy benyomás akkor jó, ha ösztönző és szórakoztató. Az Istennel való találkozás ugyanakkor sokszor megilletődést, szent félelmet, bánatot vagy a kegyelemért való könyörgés érzését is hozza. Az istentisztelet, amennyiben minden eleme a helyén van, ezt az összetett benyomást nyújtja. Így az istentisztelet hordozni fogja mind az Isten „ethosz”-át, mind pedig az emberi szenvedés „pathosz”-át. A fiataloknak feltétlenül szükségük van erre a teljességre (Edie, 2007).

A jelenkori kulturális paradigma további sajátossága az, hogy a tömegeket paszszivitásra kényszeríti. Amíg a művészetek és a látványos sportesemények teljességgel uralják az emberek életét, addig a legtöbben kívül maradnak, mind az alkotó tevékenységen, mind pedig az aktív részvételen. Az új elektronikus készülékek szintén növelik annak esélyét, hogy azok használói „belső szobáikban” kötik vagy tartják fenn kapcsolataikat, legyen szó akár számítógépről, akár más kommunikációs eszközről. Amennyiben a fiatalok - akik a legjobban érintettek az elszemélytelenedésben - az istentiszteleteken is csak passzivitásra vannak kényszerítve, úgy az egyház nem tett meg mindent ennek a folyamatnak a visszaszorítása érdekében (Novak, 2000).

Az aktív istentisztelet azonban nem azt jelenti, hogy mindenkinek minden időben teljes odaadással kell válaszolnia, énekelnie vagy akár mozdulataival jeleznie, hogy részt vesz az istentiszteleten. Az a gondolkodás, amely úgy véli, hogy ha valaki nem szól vagy énekel teljes hangerővel az istentiszteleten, az már nem is vesz részt az alkalmon, oda vezet, hogy az alkalmak túlzsúfoltak lesznek és nem lesz idő az elmélyedésre vagy a csendben elmondott reflexióra (uo. Novak, 2000).

A posztmodern társadalom és kultúra tehát újfajta válaszadásra hívja az egyházat - fogalmazza meg Kiss Sámson Endre, akinek gondolatmenetét most hosszabban követjük. Habár az evangélium kétezer év alatt nem változott, de az egyház igazodott ahhoz a kultúrához, amelyben élt. Így váltak hangsúlyossá vagy épp vesztek el különböző értékek a modern időszakban. Az egyháznak a posztmodernben felül kell vizsgálnia modern beidegződéseit és ki kell lépnie a régies gondolkodási sémákból. Csak így lehet a mai fiatalokat megszólítania (Kiss, 2009).

Hogy e jelenséget megértsük, a posztmodern fiatalok sajátos hitgyakorlatára kell koncentrálunk, különös figyelmet fordítva az istentiszteleti életüket formáló körülményekre és kihívásokra.

A posztmodern fiatal személyességre vágyik, ezt igényli az istentisztelet kialakítása is. A fiatalok általában hatalmas virtuális közösségek tagjai és kiterjedt ismerősi hálózattal rendelkeznek, de igazi, személyes találkozásokból nagyon kevés adatik nekik. Éppen ezért nem az általános igazságokkal kell hatni rájuk, hanem arra kell törekedni, hogy a fiatal személyes jelenlétünkön keresztül találkozzon Istennel. A fiatalok komolyan fogják venni azt, amit Jézus mondott, ha a gyülekezetben előbb szeretetet tapasztalnak. Ugyanígy az eukarisztia ünneplése során is előtérbe kell, hogy kerüljön a személyesség, különösen is annak kihangsúlyozásával, hogy a szentség személyes találkozási lehetőséget ad Jézussal (Kiss, 2009). 
Bár a posztmodern kor fiataljainak általános jellemzője, hogy nincs szükségük tekintélyre, ugyanakkor az is igaz, hogy a lelki vezetésre annál inkább vágynak. Az a fajta vezetés, amire a posztmodernben szükség van, nem autoratív, hanem sokkal inkább partnerség az útkeresésben. Az ifjúsággal foglalkozóknak tehát spirituális, imádkozó vezetőkké kell válniuk, akik nemcsak tanácsot tudnak adni, hanem képesek meghallgatni őket, tudnak együtt imádkozni velük, Isten szeretetét sugározzák, és áldássá tudnak válni a fiatalok számára. Ez az liturgiában úgy mutatkozhat meg, hogy a lelkipásztor nem különül el a gyülekezet tagjaitól, hanem velük együtt keresi, hívja és várja a Lelke által jelen lévő Urat. Amennyiben ebben is kifejeződik a kölcsönösség, úgy a közösség épülése is sokkal nyilvánvalóbb lesz.

A fiatalok válaszkeresése manapság sokkal szubjektívebb, mint korábban. A szellemi kutatás egy spirálvonalhoz hasonló, ahol a válasz egyre módosuló kérdéseken át közeledik. A kérdéseket újra és újra meg kell fogalmazni, és le kell mondani arról, hogy ezekre könnyen megkapjuk a végső válaszokat. Ebben a helyzetben az egyház úgy segíthet a fiatalon, hogy felkínálja Jézus Krisztust, aki maga „az út, az igazság és az élet".

Amennyiben az Ő objektív valósága szubjektívvá válhat, úgy nyílik lehetőség arra, hogy a világ által adott bizonytalan válaszok se bizonytalanítsák el a fiatalt. $\mathrm{Az}$ istentisztelet segíthet személyessé tenni Jézust, ugyanakkor nem léphet fel azzal az igényel, hogy végleges válaszokat közvetítsen. Ha azonban alkalmazkodik a hétköznapok kihívásaihoz, úgy élő lesz és táplálja az úton lévő ifjú hívőt.

A fiatalok az istentiszteletek során arra várnak, hogy a tanítás megelevenedjen, és hogy Isten Lelke elindítson bennük valamit. Ennek során olyan hatások érhetik őket, amelyet nem tudnak szavakba foglalni, de mégis tudják, hogy Isten megérintette őket. Ez különösen hangsúlyossá válhat az Isten dicsőítése során, amely a keresztyén élet csúcsa és sokszor szinte eksztatikus kifejezési módja az Isten kegyelme és irgalma iránti hálának. Ez az ünneplés nagyon fontos része az Istennel megélt kapcsolatnak, ahogyan arról Piet Fransen modelljénél már beszéltünk. Ebben jelentős szerepe van a zenének, ami azonban nem szabad, hogy manipulatív eszközzé váljon. A zene utat nyithat, de Isten Lelkének kell dolgoznia. Ugyanakkor a fiatalokat meg kell tanítani a csend szerepére is.

Ugyanígy szükséges, hogy helyet kapjon a lamentáció is, hiszen bár az ünnep nagy hangsúllyal szerepel a fiatalok életében, de sokszor kimondott vagy ki nem mondott fájdalmukkal nem tudnak mit kezdeni. Ezek mindegyikének fontos szerepe van az úrvacsora során is. Ahhoz, hogy a közösség tagjának lelki találkozása legyen az Úrral, mindezeket mint ajándékokat kell használni.

Ezek az eszközök közösséget teremtenek, amelyre a posztmodern embernek - a közhiedelemmel ellentétben - ugyanúgy igénye és szüksége van. Amitől a fiatalok félnek, és amit egyáltalán nem igényelnek az a lelki erőszak, a képmutatás, a manipulálás. Ha azonban tudunk olyan közösséget teremteni, ahol tiszteletben tartjuk 
a különbözőségeket, ragaszkodunk az őszinteséghez és nyíltan beszélünk, akkor az a közösség müködőképes lesz. Az istentiszteletnek ilyen közösségek létrehozására kell irányulnia (uo. Kiss, 2009).

Kapcsolattartó szerző:

Czagány Gábor

Gál Ferenc Egyetem

Pedagógiai Kar

6720 Szeged, Dóm tér 6.

reformatus.szeged@gmail.com
Corresponding author:

Gábor Czagány

Faculty of Pedagogy

Gál Ferenc University

Dóm square 6. 6720 Szeged, Hungary reformatus.szeged@gmail.com

\section{IRODALOMJEGYZÉK}

Csákány, T. (2001). Missziói munka az egyetemisták között. Református Egyház, 53(7-8) 184-185.

Edie, Fred. P. (2007). Book, Bath, Table, and Time. The Pilgrim Press.

Fransen, P. F. (1976). Sacraments as Celebrations. Irish Theological Quarterly, 43

(3) 151-170. https://doi.org/10.1177/002114007604300301

Kiss, S. E. (2009). Posztmodern fiatalok megszólítása. Református Egyház 61(12) 281-287.

Novak, M. (2000). Ready to Assemble: Youth as Part of Liturgical Assembly. In Singer-Towns B. (Ed.), Vibrant Worship with Youth. (35-46). St Mary's Press.

P. Tóth, B. (1996). Pásztorálpszichológia és tanácsadás - a valláslélektan gyakorlati alkalmazása. Theológiai Szemle 39(2) 62-75. 